\title{
CONGRESS AND THE EXECUTIVE: CHALLENGING THE ANTI-REGULATORY NARRATIVE
}

\author{
Richard L. Revesz ${ }^{*}$ \\ 2018 VISIONARY ARTICLE IN ENVIRONMENTAL LAW AND \\ REGULATORY POLICY
}

2018 MiCH. ST. L. REV. 795

\begin{abstract}
Recently, critics of the administrative state have been urging Congress to reassert itself and rein in regulatory action that they maintain is both undesirable as a matter of policy and in violation of constitutional principles. This anti-regulatory position is unwarranted. While regulatory agencies have indeed been more active in recent decades - in part due to increasing gridlock in Congress - the resulting regulatory actions produced large net benefits to the American people and were carried out pursuant to authority delegated by Congress and reviewed by the courts. By contrast, more robust action by Congress, as long as Congress continues to exhibit its current pathologies, is unlikely to be beneficial. Furthermore, in a troubling development, the Trump Administration has turned away from cost-benefit analysis in order to carry out its anti-regulatory agenda, disregarding an established bipartisan consensus that stretched back several decades.
\end{abstract}

\section{TABLE OF CONTENTS}

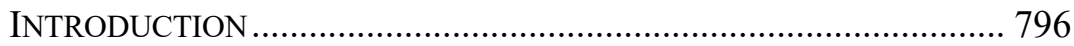

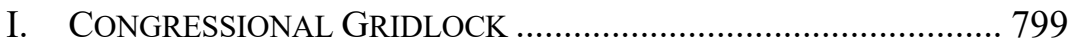

II. EXECUTIVE BRANCH ACTIVITY .............................................. 802

III. DESIRABILITY OF REGULATORY ACTIVITY ............................ 807

IV. SEPARATION OF POWERS CONCERNS .................................... 809

V. A MoRe Robust CONGRESSIONAL Role? ........................... 814

* Lawrence King Professor of Law and Dean Emeritus, New York University School of Law. The generous financial support of the Filomen D'Agostino and Max Greenberg Research Fund at NYU Law School is gratefully acknowledged. This piece grew out of a blog post titled Challenging the Anti-Regulatory Narrative published in The Regulatory Review on July 23, 2018. I am very grateful to Ben Morris for excellent research assistance. 


\section{THE CURRENT ADMINISTRATION'S DISREGARD FOR}

COST-BENEFIT ANALYSIS 817

\section{INTRODUCTION}

Over the last decade, critics of the regulatory state have complained that an out-of-control executive branch has harmed the American people and the American economy, and that Congress needs to reassert itself and constrain this misbehavior. ${ }^{1}$ Though criticism of executive branch agencies is certainly not a new development in American political debate, historically critics often demanded stronger presidential control of the administrative state. ${ }^{2}$ Recently, however, with increasing concern from both the right and the left about the expanding power of the president, the tenor of anti-regulatory attacks has shifted to call on Congress to step up and rein in the "Executive," more broadly defined to include the president as well as agencies. ${ }^{3}$

1. See F. H. Buckley, The Once and Future King: The Rise of Crown GOVERNMENT IN AMERICA 12-13 (2015) (arguing that the accumulation and centralization of power under the president threatens the American constitutional system); Philip Hamburger, Is Administrative Law Unlawful? 31 (2014) (arguing that administrative lawmaking represents a form of extralegal governance fundamentally at odds with the U.S. constitutional scheme); Gillian E. Metzger, $1930 \mathrm{~s}$ Redux: The Administrative State Under Siege, 131 HARV. L. REV. 1, 6 (2017) (framing the recent criticism of the administrative state in the context of attacks on the New Deal); Cass R. Sunstein \& Adrian Vermeule, The New Coke: On the Plural Aims of Administrative Law, 2015 SuP. CT. REV. 41, 46-47 (highlighting the parallels drawn in modern critiques of the executive power and the administrative state to the despotism and lawlessness of the Stuart kings); Douglas H. Ginsburg, Delegation Running Riot, 1 Reg. 83, 83-84 (1995) (citing DAvid SchOENBROD, Power Without Responsibility: How Congress Abuses the People Through DELEGATION (1993)) (arguing that the New Deal had "banished . . the Constitution of liberty").

2. See Steven G. Calabresi \& Kevin H. Rhodes, The Structural Constitution: Unitary Executive, Plural Judiciary, 105 HARV. L. REV. 1153, 1165-66 (1992) (summarizing arguments for the "unitary executive" theory of stronger presidential control of the executive branch); Metzger, supra note 1, at 32 (comparing recent "alarms about burgeoning presidential power" to Reagan-era attacks of "restrictions on presidential authority"); Morton Rosenberg, Congress's Prerogative over Agencies and Agency Decisionmakers: The Rise and Demise of the Reagan Administration's Theory of the Unitary Executive, 57 GEO. WASH. L. REV. 627, 62829 (1989) (observing that President Reagan was unable to achieve his deregulatory goals through legislation and instead turned to "aggressive administrative strategy," including centralized oversight of agencies).

3. See BuCKLEY, supra note 1, at 152-57 (alleging that administrative rulemaking works to consolidate power in the president at the expense of Congress); Sunstein \& Vermeule, supra note 1, at 46 (noting that the so-called Constitution-inExile Movement is a "wholesale critique of modern exercises of administrative power," though the movement is "broad and ill-defined"). Sunstein and Vermeule also 
Calls for Congress to wield more control over the executive branch grew louder during the Obama presidency, when Republicans in Congress sought ways to challenge a Democrat in the White House. ${ }^{4}$ However, the criticism - of the administrative state and, less vigorously, of the role of the president - continues under the Trump Administration, despite Republican control of the White House and both houses of Congress. ${ }^{5}$

I disagree with both the diagnosis of the illness - that the regulatory state is out of control - and the cure - that Congress needs to exercise firmer oversight over the executive branch. Though separation of powers concerns have also been hotly debated in recent years regarding presidential action on foreign policy, war-making, and homeland security, ${ }^{6}$ my focus in this piece is on regulatory policy.

note a related thread of criticism from the left towards executive power arising during the George W. Bush Administration regarding Guantanamo Bay and the Patriot Act. See Sunstein \& Vermeule, supra note 1, at 46.

4. See Jared A. Goldstein, The Tea Party Movement and the Perils of Popular Originalism, 53 ARIZ. L. REV. 827, 832-35 (2011) (describing the rise of the Tea Party as a popular, constitutional movement responding to President Obama's policies). Obama's presidency, from 2009 to 2016, coincided - not incidentallywith a period of heated debate around the constitutional place of the administrative state. See infra Part II (noting that Obama tried to implement policies through regulation in light of the gridlock in Congress).

5. Congress is still considering regulatory reform bills, such as the Regulatory Accountability Act and the Regulations from the Executive in Need of Scrutiny Act, which would significantly curtail the president's power to control the administrative state. See Christopher J. Walker, Modernizing the Administrative Procedure Act, 69 ADMIN. L. REV. 629, 631 (2017) (highlighting that Republican calls for regulatory reform have not disappeared during the Trump Administration); Philip A. Wallach, The Ironic Politics of Regulatory Reform, Brookings (Mar. 26, 2018), https://www.brookings.edu/research/the-ironic-politics-of-regulatory-reform/

[https://perma.cc/APK3-7R3B] (describing the political dynamics of support for the Regulatory Accountability Act, which would constrain the Trump Administration, but enjoys support from Republicans but not Democrats); Philip A. Wallach \& Nicholas W. Zeppos, Will Congress and President Trump Be Collaborators or Combatants on Regulatory Reform?, BROOKINGS (Feb. 1, 2017), https://www.brookings.edu/ research/will-congress-and-president-trump-be-collaborators-or-combatants-onregulatory-reform/ [https://perma.cc/K9KY-YMPV] (questioning whether Trump will support reforms to the administrative state that would give Congress more power at the expense of the executive branch). Though legislation is still on the table, Republicans have been less outspoken in criticizing President Trump's role in overseeing the administrative state than they were of President Obama's. See Richard J. Pierce, Jr., Republicans Discover the Mythical Basis for Regulatory Reform, REG. REV. (Jan. 30, 2018), https://www.theregreview.org/ 2018/01/30/pierce-republicans-mythical-basis-regulatory-reform/

[https://perma.cc/G3NN-6RCJ] (noting that proposals for reform of the rulemaking process have "all but vanished" from Republicans' agenda since Trump took office).

6. See, e.g., Bruce Ackerman, The Emergency Constitution, 113 YALE L.J. $1029,1030-31$ (2004) (reconsidering the president's emergency powers in the face of 
And, within the domain of regulatory policy, my focus is on environmental regulation, particularly regulation under the Clean Air Act, where the benefits and costs of regulation are highest, ${ }^{7}$ and the vitriol of regulatory opponents has been especially pronounced. ${ }^{8}$

The criticism of the regulatory state breaks down into five propositions: first, that Congress is paralyzed by gridlock; second, that the executive branch has stepped into the breach; third, that this result is undesirable as a matter of policy; fourth, that it is an affront to our

the threat of terrorism); Bruce Ackerman \& Oona Hathaway, Limited War and the Constitution: Iraq and the Crisis of Presidential Legality, 109 MicH. L. REv. 447, 450 (2011) (arguing that the Iraq War "represented a breathtaking assertion of presidential authority to redefine war aims without the consent of Congress"); Daphne Barak-Erez, Terrorism Law Between the Executive and Legislative Models, 57 AM. J. COMP. L. 877, 878-79 (2009) (noting examples of executive actions on anti-terrorism taken by President Obama that cut out Congress); Laura A. Dickinson, Using Legal Process to Fight Terrorism: Detentions, Military Commissions, International Tribunals, and the Rule of Law, 75 S. CAL. L. REV. 1407, 1415-21 (2002) (discussing constitutional implications of executive action on detentions and military tribunals); Neal K. Katyal \& Laurence H. Tribe, Waging War, Deciding Guilt: Trying the Military Tribunals, 111 YALE L.J. 1259, 1260 (2002) (arguing that President Bush's order that established military tribunals, which were not authorized by Congress, was "flatly unconstitutional"); Peter Margulies, Judging Terror in the "Zone of Twilight": Exigency, Institutional Equity, and Procedure after September 11, 84 B.U. L. REV. 383, 388 (2004) (advocating for an approach to emergency powers that "allocate[s] the risk of uncertainty that crisis yields between the three branches").

7. See Office of Mgmt. \& Budget, Office of Info. \& Regulatory AfFAirs, 2017 Draft REPORT TO CONGRESS ON THE BENEFITS AND COSTS OF FEDERAL Regulations and Agency Compliance With the Unfunded Mandates Reform ACT 12 (2017), https://www.whitehouse.gov/wp-content/uploads/2017/12/

draft_2017_cost_benefit_report.pdf [https://perma.cc/T8SE-82TY] (finding EPA regulations to constitute over $80 \%$ of monetized benefits and over $70 \%$ of monetized costs of major federal regulations).

8. See Coral Davenport, EPA: The World in Microcosm, NAT'L J. (Sept. 22, 2011) [hereinafter The World in Microcosm] (describing the EPA as the "the poster child for expanded government control"); Coral Davenport, E.P.A Faces Bigger Tasks, Smaller Budgets and Louder Critics, N.Y. Times (Mar. 18, 2016), https://www.nytimes.com/2016/03/19/us/politics/epa-faces-bigger-tasks-smallerbudgets-and-louder-critics.html [https://perma.cc/HB4Q-3DJF] (describing the EPA as a "favorite political target for Republicans"); Stephen Power, Environment Chief Caught in the Campaign Crossfire, WALL ST. J. (Oct. 8, 2010), https://www.wsj.com/articles/SB10001424052748704847104575532243548950392 [https://perma.cc/88ZQ-QSK5] (highlighting that Tea Party candidates in 2010 blamed many of the country's problems on environmental regulation); Cristine Russell, Bill Ruckelshaus on EPA: 'Battered Agency Syndrome?', ATLANTIC (Dec. 4, 2010), https://www.theatlantic.com/technology/archive/2010/12/bill-ruckelshaus-onepa-battered-agency-syndrome/67501/ [https://perma.cc/FY8L-BDPF] (describing EPA as "a lightning rod for the anti-government fervor that strikes Washington on a regular basis"). 
constitutional system of separation of powers; and, fifth, that to solve this problem, Congress should assert greater control over administrative agencies. I agree with the first two propositions, disagree with the next three, and have a deep concern about a recent, related turn of events: the Trump Administration's turn away from cost-benefit analysis as an organizing principle for the administrative state.

\section{CONGRESSIONAL GRIDLOCK}

On the first proposition, there is a general consensus in the academic literature ${ }^{9}$ and in the media ${ }^{10}$ that Congress has become increasingly gridlocked in recent years. Though commentators take

9. See, e.g., Thomas E. MAnn \& Norman Ornstein, It's Even Worse Than IT LoOKS: How the AmERicAn CONSTitutional System Collided with THE New Politics OF EXTREMism 101 (2012) (arguing that "[t]he single-minded focus on scoring political points over solving problems ... has reached a level of such intensity and bitterness that the government seems incapable of taking and sustaining public decisions responsive to the existential challenges facing the country"); SARAH Binder, Polarized We Govern? 11-16 (2014), https://www.brookings.edu/wpcontent/uploads/2016/06/BrookingsCEPM_Polarized_figReplacedTextRevTableRev .pdf [https://perma.cc/P4Y4-8KGV] (demonstrating a trend of increasing congressional gridlock since the mid-twentieth century); Joseph P. Tomain, Gridlock, Lobbying, and Democracy, 7 WAKE FOREST J.L. \& POL'Y 87, 89 (2017) (observing that the prevalence of micro-level gridlock is "a standstill between wealthy corporate interests with political access and the rest of America"); Barbara Sinclair, Is Congress Now the Broken Branch?, 2014 UTAH L. REV. 703, 704 (noting that recent developments raise concerns "about the contemporary Congress's capacity to adequately perform its central functions").

10. See, e.g., Sheryl Gay Stolberg \& Nicholas Fandos, As Gridlock Deepens in Congress, Only Gloom Is Bipartisan, N.Y. TIMES (Jan. 27, 2018), https://www.nytimes.com/2018/01/27/us/politics/congress-dysfunction-conspiraciestrump.html [https://perma.cc/R2S7-8PV4] (discussing the past and potential future governmental shutdowns during the Trump presidency); Chris Cillizza, The Least Productive Congress Ever, WASH. Post (July 17, 2013),

http://www.washingtonpost.com/blogs/the-fix/wp/2013/07/17/the-least-productivecongress-ever/ [https://perma.cc/8J6A-5PAT] (pointing out that the 112th Congress (2011-2012) had passed fewer bills than any Congress since 1947 when the statistic started being tracked); Toluse Olorunnipa, Trump's Governing Just Like Obama with Congress Gridlocked, BLOOMBERG (Apr. 3, 2018, 4:00 AM),

https://www.bloomberg.com/news/articles/2018-04-03/trump-s-pen-and-phonepresidency-begins-as-congress-gridlocks [https://perma.cc/HK8G-YYTL] (noting that President Trump has become frustrated with congressional inactivity and is relying on executive power to try to make progress on his agenda); David Faris, Why the GOP Congress Will Be the Most Unproductive in 164 Years, WeEK (July 18, 2017), http://theweek.com/articles/711503/why-gop-congress-most-unproductive164-years [https://perma.cc/8QXS-BEDD] (attributing gridlock to polarization between parties and within the Republican party). 
different approaches to measuring gridlock, ${ }^{11}$ many consider some measure of legislative output to gauge legislative productivity and, by implication, gridlock. ${ }^{12}$ Though the most straightforward approach to measuring legislative output is to compare numbers of bills passed or the page-length of bills passed across Congresses, these statistics may be misleading as not all bills are equally significant, and not all Congresses have equally urgent legislative agendas. ${ }^{13}$ Additionally, gridlock is generally defined as a failure of Congress to make substantive policy decisions, so lack of legislative productivity is not a perfect proxy: A decision by Congress to maintain the status quo is not an example of gridlock, though that decision might result in no legislative output. ${ }^{14}$

One oft-cited study of gridlock considers the percentage of the "salient" legislative items - defined as those items that are covered in at least four editorials in The New York Times - that failed to pass. ${ }^{15}$ According to a recent study, under this measure, the 112th Congress (2011-2012) was one of the two least productive Congresses between 1947 and 2012, failing to pass $71 \%$ of salient legislative items on its agenda. ${ }^{16}$ More generally, the study found an upward trend in gridlock with the trendline nearly doubling from about 30\% of salient legislative items gridlocked in the mid-twentieth century to almost $60 \%$ gridlocked in $2012 .{ }^{17}$ The concern about congressional gridlock has not abated during the Trump presidency, despite Republicans controlling both houses of Congress and the presidency. ${ }^{18}$

Signs of gridlock can be observed beyond strict legislative output as well. Congressional scholar Barbara Sinclair has pointed to the rise in the use of "unorthodox" congressional procedures - such as omnibus bills, post-committee adjustments, and changes in parliamentary rules - as a symptom of worsening gridlock. ${ }^{19}$ These

11. Professor Teter describes congressional gridlock as having "a "know it when you see it' feel." Michael J. Teter, Congressional Gridlock's Threat to Separation of Powers, 2013 WIS. L. REV. 1097, 1102.

12. See generally David R. Mayhew, Divided We Govern: Party Control, LAWMAKING, AND INVESTIGATIONS, 1946-2002 (2d ed. 2005) (attempting to rigorously quantify congressional gridlock for the first time).

13. See Teter, supra note 11, at 1105 .

14. See id. at 1102-03, 1102 n.17.

15. See BINDER, supra note 9, at 5 n.2, 8-9. The methodology of the study is designed to control for the size of a given Congress's legislative agenda rather than merely counting total bills or total pages of bills with no filter. See id.

16. See id. at fig.3.

17. See id.

18. See Stolberg \& Fandos, supra note 10.

19. See Barbara Sinclair, Unorthodox Lawmaking: New Legislative Processes IN the U.S. Congress 235 (2d ed. 2000); see also Abbe R. Gluck, 
less-formal procedures decrease deliberation and transparency in the lawmaking process, but, given the difficulty Congress has in passing any laws during periods of gridlock, cutting procedural corners appears to be the only way for Congress to get anything at all done. ${ }^{20}$ In a similar vein, in the Senate, the increased use of filibusters and the cloture rule supports the conclusion of worsening gridlock. ${ }^{21}$ From 1917, when the cloture rule was first adopted, to 1988, a total of 385 motions to invoke cloture were filed; that number was surpassed in just a six-year span from 2007 to 2013 with 391 cloture motions. ${ }^{22}$ Where filibusters used to be relatively rare, they have now become a key weapon in the arsenal of a minority party trying to obstruct potential legislation. ${ }^{23}$

Various factors have been suggested to explain the current extreme levels of congressional gridlock. ${ }^{24}$ For example, an increase in the frequency of divided government could lead to more periods in which Congress expects to be less productive and focuses more on obstruction than on trying to compromise on passing legislation. ${ }^{25}$ More extreme polarization between congressional members of different parties, with fewer moderates in Congress, means that reaching across the aisle to build consensus to pass legislation is less likely to be fruitful. ${ }^{26}$ Also, congressional districts are becoming less

Imperfect Statutes, Imperfect Courts: Understanding Congress's Plan in the Era of Unorthodox Lawmaking, 129 HARV. L. REV. 62, 76 (2015) (describing the Affordable Care Act as "a textbook example of the modern trend toward nontextbook, or 'unorthodox,' lawmaking").

20. See SinclaIR, supra note 19 , at 235.

21. See id. at 107.

22. See Teter, supra note 11, at 1107.

23. See id.

24. See Richard L. Revesz, Regulation and Distribution, 93 N.Y.U. L. REV. (forthcoming 2018) (manuscript at 26-28) (on file with author) (explaining various reasons for gridlock).

25. See id. at 26-27; see also Fang-Yi Chiou \& Lawrence S. Rothenberg, When Pivotal Politics Meets Partisan Politics, 47 Am. J. Pol. ScI. 503, 518 (2003); Sarah A. Binder, The Dynamics of Legislative Gridlock, 1947-96, 93 Am. PoL. SCI. ReV. 519, 530 (1999); John J. Coleman, Unified Government, Divided Government, and Party Responsiveness, 93 AM. Pol. ScI. ReV. 821, 825-26, 832 (1999).

26. See Brian F. Schaffner, Party Polarization, in The Oxford HandBook OF THE AMERICAN CONGRESS 527, 539 (Eric Schickler \& Frances E. Lee eds., 2011) (describing studies that have connected polarization and gridlock); Daryl J. Levinson \& Richard H. Pildes, Separation of Parties, Not Powers, 119 Harv. L. Rev. 2311, 2338 (2006) (arguing that "cohesive and polarized parties" can help explain the current dynamics in Congress); Revesz, supra note 24, at 27 (noting that gridlock tends to increase when there are fewer moderates in Congress); Sinclair, supra note 9, at 716 (noting that compromise is less likely where there are greater differences between preferences of the two major parties). Some scholars have noted, however, that polarization alone does not invariably lead to gridlock. See, e.g., Richard H. 
competitive between the parties, in part due to gerrymandering. ${ }^{27}$ As a result, instead of facing a threat from a candidate of the other party, members of Congress may be more likely to face serious opposition in a primary challenge from a more ideologically extreme candidate within their own party, making compromise across the aisle less helpful in elections than ideological purity. ${ }^{28}$ At the same time, the polarized media landscape helps push voters' views to the extremes. ${ }^{29}$ And, finally, with the amount of money flowing into politics today, politicians may feel their hands are tied on issues that are salient to their biggest donors, making those politicians unwilling to seek compromise. ${ }^{30}$

\section{EXECUTIVE BRANCH ACTIVITY}

On the second proposition - that the executive branch has tried to fill the void cause by congressional gridlock - it is fair to say that the Obama Administration ushered in a healthy dose of regulatory activity. ${ }^{31}$ Running for president in the midst of an economic recession

Pildes, Romanticizing Democracy, Political Fragmentation, and the Decline of American Government, 124 YALE L.J. 804, 809-10 (2015) (describing how the American party system looks increasingly like a parliamentary party system, which is ineffective without strong power and leadership within the parties).

27. See MANn \& ORnstein, supra note 9, at 46; Thomas E. Mann, Polarizing the House of Representatives: How Much Does Gerrymandering Matter?, in 1 RED and Blue Nation?: Characteristics and CAuses of America's Polarized Politics 263, 268-69 (Pietro S. Nivola \& David W. Brady eds., 2006); Levinson \& Pildes, supra note 26, at 2335; Revesz, supra note 24, at 27.

28. See Mann, supra note 27, at 267; Revesz, supra note 24, at 27-28; Schaffner, supra note 26, at 535; Thomas Stratmann, Congressional Voting over Legislative Careers: Shifting Positions and Changing Constraints, 94 AM. POL. SCI. REV. 665, 672 (2000).

29. See MAnn \& ORnstein, supra note 9, at 58; Barbara Sinclair, PARTY Wars: Polarization And the Politics of National Policy Making 63-64 (2006); Nicholas T. Davis \& Johanna L. Dunaway, Party Polarization, Media Choice, and Mass Partisan-Ideological Sorting, 80 PuB. OPINION Q. 272, 292 (2016); Revesz, supra note 24, at 28; Daniel F. Stone, Media and Gridlock, 101 J. PuB. Econ. 94, 101 (2013).

30. See Mann \& ORnstein, supra note 9, at 80; Ruben J. Garcia, Politics at Work after Citizens United, 49 Loy. L.A. L. REv. 1, 10 (2016); Gerard N. Magliocca, Don't Be So Impatient, 88 Notre Dame L. Rev. 2157, 2160 n.16 (2013); Revesz, supra note 24, at 28; Ray La Raja, The Supreme Court Might Strike Down Overall Contribution Limits. And That's Okay., WAsH. Post (Oct. 9, 2013), https://www.washingtonpost.com/news/monkey-cage/wp/2013/10/09/the-supremecourt-might-strike-down-overall-contribution-limits-and-thatsokay/?utm_term=.f4716b9a9447 [https://perma.cc/SC86-KNEQ].

31. See, e.g., Jeff Jacoby, Obama Threw the Regulatory Engine into Overdrive. Trump Is Slowing it Down, Bos. GlobE (Apr. 25, 2018), https://www.bostonglobe.com/opinion/2018/04/25/obama-threw-regulatory-engine- 
in 2008, then-candidate Obama placed much of the blame for the recession on the deregulation of the financial sector that had occurred in the preceding decades. ${ }^{32}$ In one speech, criticizing the deregulatory policies of previous administrations, he proclaimed: "Instead of establishing a 21st century regulatory framework, we simply dismantled the old one..." 33 The open rhetorical embrace of regulation marked a stark contrast to the politics of the 1990s and the earlier 2000s, where both parties had tried to cut back or streamline federal regulation. ${ }^{34}$

Though financial regulation and efforts to promote economic recovery captured a lot of attention in Obama's first term, the administration was broadly aggressive in promulgating new rules and enforcing existing ones, with the Environmental Protection Agency (EPA) being one of the most aggressive actors advancing this new

into-overdrive-trump-slowing-down/jKEXwmsieAhCUK7Vf2IiEO/story.html [https://perma.cc/KY4T-G7A7] (noting that as a presidential candidate in 2008, Obama blamed deregulation for the economic crisis and vowed to regulate more actively); Eric Lipton, With Obama, Regulations Are Back in Fashion, N.Y. TIMES (May 12, 2010), https://www.nytimes.com/2010/05/13/us/politics/13rules.html?

r=2\&pagewanted=all [https://perma.cc/S2N3-YLHR] (explaining that the Obama $\bar{A}$ dministration had not only been aggressive in promulgating new rules but also in stepping up enforcement or rules); Susan E. Dudley \& Daniel R. Pérez, President's State of the Union Suggests Final Regulatory Push, Forbes (Jan. 13, 2016, 12:00 PM), https://www.forbes.com/sites/susandudley/2016/01/13/presidents-state-of-theunion-suggests-final-regulatory-push/\#2c002d4279b2 [https://perma.cc/X65ZJNXU] (highlighting that the Obama Administration had outpaced the Clinton and both Bush Administrations in the number of economically significant regulations); Daniel R. Pérez, President Obama's Regulatory Output: Looking Back at 2015 and Ahead to 2016, Geo. Wash. Univ. Reg. Stud. CTr. (Jan. 12, 2016), https://regulatorystudies.columbian.gwu.edu/president-obama's-regulatory-outputlooking-back-2015-and-ahead-2016 [https://perma.cc/2Y7Y-KANG] (demonstrating that the Obama Administration enacted more economically significant regulations in 2015 than had been passed in the second to last year in the Clinton and George W. Bush Administrations). Though the methodological challenges in measuring levels of regulation are beyond the scope of this Article, the regulatory efforts of the Obama Administration are generally deemed to have been more vigorous than those of its recent predecessors. See Lipton, supra.

32. See Michael Powell, Obama Urges Regulation in Wake of Housing Slump, N.Y. TIMES (Mar. 27, 2008), https://www.nytimes.com/2008/03/27/ us/politics $/ 27 \mathrm{cnd}$-dems.html?ex=1364356800\&en=1f7f7529c7cec326\&ei=5088\& partner=rssnyt\&emc $=$ rss [https://perma.cc/YJ5E-BHVN].

33. Id.

34. See James Ridgeway, It's the Deregulation, Stupid, Mother Jones (Mar. 28, 2008, 7:00 AM), https://www.motherjones.com/politics/2008/03/its-deregulationstupid/ [https://perma.cc/V3LE-NMWK] (noting that "'regulation' is no longer such a dirty word"). 
regulatory agenda. ${ }^{35}$ In particular, the EPA sought to address significant air pollution problems that posed serious harms to public health, in some cases carrying out nondiscretionary statutory duties and in others exercising its discretion pursuant to congressional delegations. ${ }^{36}$

Though responding to deregulatory tendencies of previous administrations was one motivation for the increase in regulatory activity under Obama, congressional gridlock provided another motivation. ${ }^{37}$ To respond to climate change and air pollution challenges, the Obama Administration initially pushed for a legislative solution with a cap-and-trade bill. ${ }^{38} \mathrm{~A}$ bill targeting greenhouse gas emissions passed in the House in 2009 with only eight Republican votes. ${ }^{39}$ Republicans, complaining about the high cost of the bill, had proposed over 400 amendments in the markup session. ${ }^{40}$ The fight in the Senate would prove to be even more difficult, as Democrats needed sixty votes to overcome a potential Republican filibuster. ${ }^{41}$ While some Democrats from coal and oil states were unwilling to support a Democratic-sponsored bill, a more moderate, bipartisan version was unable to attract enough Republican votes to overcome a potential filibuster. ${ }^{42}$ In the end, no version of a cap-and-trade bill was brought to the floor of the Senate for a vote. ${ }^{43}$ Republicans, criticizing

35. See Lipton, supra note 31 (stating the scale of rulemaking in the Obama Administration was higher than in the Clinton and Bush Administrations, according to several common metrics used to estimate aggregate regulatory volume); Reg Stats, GeO. WASh. UnIV. REG. STUD. CTR., https://regulatorystudies.columbian.

gwu.edu/reg-stats [https://perma.cc/3GKU-69FD] (last visited Nov. 18, 2018). For example, 489 economically significant rules were promulgated across all agencies under Obama compared to 361 under Clinton and 358 under Bush. See Reg Stats, supra note 35 .

36. See Thomas O. McGarity, Avoiding Gridlock Through Unilateral Executive Action: The Obama Administration's Clean Power Plan, 7 WAKE ForEST J. L. \& PoL'Y 141, 149-52, 156-57, 163-64, 169-70, 173-74, 177-79, 188-89 (2017) (cataloguing the regulations promulgated by Obama's EPA); The World in Microcosm, supra note 8.

37. See McGarity, supra note 36, at 198.

38. See Eric Pooley, The Climate War: True Believers, Power Brokers, and the Fight to SAVe the EArth 326 (1st ed. 2010) (noting President Obama called for climate legislation in the form of a "market-based cap on carbon pollution" in his first address to Congress in 2009).

39. See McGarity, supra note 36 , at 146.

40. See Pooley, supra note 38, at 387-88; McGarity, supra note 36, at 145.

41. See McGarity, supra note 36, at 146-47.

42. See PoOLEY, supra note 38, at 418-19; McGarity, supra note 36, at 146.

43. See With a Whimper, N.Y. Times (July 22, 2010), https://www.nytimes.com/2010/07/23/opinion/23fril.html [https://perma.cc/WK5HVNQH]. 
the environmental platform of the Obama Administration, ${ }^{44}$ won major victories in the 2010 midterm elections. Retaking the House and picking up six seats in the Senate, Republicans vowed to continue their efforts to block Obama's agenda in Congress. ${ }^{45}$

The day after the midterm elections, recognizing that a comprehensive legislative solution to tackle greenhouse gas emissions would likely be impossible, Obama observed that "[c]ap and trade was just one way of skinning the cat; it was not the only way." 46 In his second term, Obama would shift his focus from advocating for a legislative solution to combat greenhouse gas emissions to pushing EPA-promulgated regulations under existing statutory authority. ${ }^{47}$

From the start of his first term, Obama's EPA had already been active in promulgating rules to protect the environment, processing a backlog of court-ordered regulations dating back as long as twenty years. ${ }^{48}$ In its landmark decision Massachusetts v. EPA, for example, the Supreme Court held that greenhouse gas emissions from vehicles qualified as air pollutants under the Clean Air Act and would be subject to regulation if the EPA made a finding that these emissions endangered human health and welfare. ${ }^{49}$ In 2009, the EPA issued the "[e]ndangerment [f]inding" (that greenhouse gas emissions from vehicles did indeed endanger human health and welfare $)^{50}$ followed by rules that set out the plan to regulate greenhouse gas emissions from vehicle tailpipes and stationary sources..$^{51}$ Another rule, the Mercury

44. See Power, supra note 8.

45. See Dan Balz \& William Branigin, After Midterm Wins, GOP Vows to Block Obama's Agenda, WASH. Post (Nov. 3, 2010), http://www.washingtonpost.com/wp-dyn/content/article/2010/11/02/ AR2010110207506.html?sid=ST2010110201489 [https://perma.cc/V6T7-4CCE].

46. John M. Broder, Obama to Face New Foes in Global Warming Fight, N.Y. Times (Nov. 3, 2010), https://www.nytimes.com/2010/11/04/ business/energy-environment/04enviro.html [https://perma.cc/S9Z5-M7U5].

47. See Peter Baker \& Coral Davenport, Using Executive Powers, Obama Begins His Last Big Push on Climate Policy, N.Y. Times (May 31, 2014), https://www.nytimes.com/2014/06/01/us/politics/obama-sets-the-stage-for-curbingemissions.html [https://perma.cc/CMK7-AKBA].

48. See The World in Microcosm, supra note 8.

49. See Massachusetts v. EPA, 549 U.S. 497, 529, 533 (2007).

50. See Endangerment and Cause or Contribute Findings for Greenhouse Gases, 74 Fed. Reg. 66,496, 66,496 (Dec. 15, 2009) (to be codified at 40 C.F.R. ch. $1)$.

51. See Reconsideration of Interpretation of Regulations, 75 Fed. Reg. 17,004, 17,019 (Apr. 2, 2010) (to be codified at 40 C.F.R. pts. 50, 51, 70, 71) (announcing that vehicular greenhouse gas emissions standards would trigger stationary-source permitting requirements); Light-Duty Vehicle Greenhouse Gas Emission Standards, 75 Fed. Reg. 25,324, 25,396 (May 7, 2010) (to be codified at 40 C.F.R. pts. 85, 86, 600; 49 C.F.R. pts. 531, 533, 536, et al.) (setting tailpipe emission 
and Air Toxics Standards (MATS) rule, finalized at the end of 2011, was based on the results of a congressionally mandated study completed in 1997.52 Litigation initiated in 2008, which charged the EPA with a failure to fulfill a non-discretionary duty to act, was settled with a consent decree that set a deadline of December 16, 2011, for a notice of final rulemaking for what became the MATS rule. ${ }^{53}$ Yet another rule, the Cross-State Air Pollution Rule (CSAPR), originally published in 2011 (and subsequently updated), replaced the 2005 Clean Air Interstate Rule (CAIR), which had been struck down 2008 by the U.S. Court of Appeals for the D.C. Circuit. ${ }^{54}$

In his second term, President Obama more aggressively used his position as president to take a strong leadership role in setting the EPA agenda. In 2013, he announced an ambitious "Climate Action Plan" and ordered the EPA to publish notices of proposed rulemaking to combat greenhouse gas emissions..$^{55}$ The EPA responded with several rules targeting the greenhouse gas emissions of power plants: the Clean Power Plan (CPP), which limits the carbon dioxide emissions of existing power plants, ${ }^{56}$ rules limiting the carbon dioxide emissions standards of new and modified power plants, ${ }^{57}$ and the methane emissions standards of new and modified oil and gas installations. ${ }^{58}$ With these moves, President Obama explicitly embraced unilateral executive action to tackle climate change, calling it "a challenge that does not pause for partisan gridlock." ${ }_{59}$

standards for vehicles); Prevention of Significant Deterioration and Title V Greenhouse Gas Tailoring, 75 Fed. Reg. 31,514, 31,516 (June 3, 2010) (to be codified at 40 C.F.R. pts. 51, 52, 70, et al.) (laying out tailoring of stationary-source requirements to include greenhouse gas emission regulations).

52. See National Emission Standards for Hazardous Air Pollutants, 77 Fed. Reg. 9,304, 9,306 (Feb. 16, 2012) (to be codified at 40 C.F.R. pts. 60, 63).

53. See id. at 9,436 .

54. See Federal Implementation Plans, 76 Fed. Reg. 48,207, 48,211 (Aug. 8, 2011) (to be codified at 40 C.F.R. pts. 51, 52, 72, et al.).

55. See Exec. Office of the President, The President's Climate Action PLAN 7 (2013), https://obamawhitehouse.archives.gov/sites/default/files/image/ president27sclimateactionplan.pdf [https://perma.cc/77KS-L463].

56. See Carbon Pollution Emission Guidelines for Existing Stationary Sources, 80 Fed. Reg. 64,661, 64,663 (Oct. 23, 2015) (to be codified at 40 C.F.R. pt. $60)$.

57. See Standards of Performance for Greenhouse Gas Emissions, 80 Fed. Reg. 64,510, 64,510 (Oct. 23, 2015) (to be codified at 40 C.F.R. pts. 60, 70, 71, et al.).

58. See Oil and Natural Gas Sector, 81 Fed. Reg. 35,824, 35,825 (June 3, 2016) (to be codified at 40 C.F.R. pt. 60).

59. Barack Obama, U.S. President, Remarks by the President on Climate Change at Georgetown University (June 25, 2013), https://www.whitehouse.gov/ the-press-office/2013/06/25/remarks-president-climate-change [https://perma.cc/TP5Y-MWEM]; see also Baker \& Davenport, supra note 47. 


\section{DESIRABILITY OF REGULATORY ACTIVITY}

The third claim, that this development is undesirable as a matter of policy, is, according to the best analyses of costs and benefits of regulations, patently incorrect. Every regulatory impact analysis of recent, major air-quality regulations has shown that these regulations produce enormous net benefits (that is, benefits minus costs). Since 1981, every president has had in place an Executive Order requiring that, except where otherwise provided for by statute, major federal regulations be justified by reference to cost-benefit analysis. ${ }^{60}$ The purpose is to allow for effective oversight of agency rulemaking to ensure that benefits of major rules justify their costs. ${ }^{61}$ In order to satisfy this requirement, agencies must perform regulatory impact analyses for major rules, subject to review by the Office of Information and Regulatory Affairs (OIRA) in the Office of Management and Budget (OMB). ${ }^{62}$

In its 2017 summary of the costs and benefits of all major federal regulations for which costs and benefits had been estimated, the OMB reported aggregate benefits of between $\$ 287$ and $\$ 911$ billion and costs of only between $\$ 78$ and $\$ 115$ billion. ${ }^{63}$ Of these regulations, EPA rules account for over $80 \%$ of all monetized benefits - between $\$ 240$ and $\$ 784$ billion-and over $70 \%$ of all monetized costsbetween $\$ 65$ and $\$ 85$ billion. ${ }^{64}$ The EPA has also completed three comprehensive studies of the costs and benefits of the Clean Air Act, with the most recent published in 2011.65 This prospective study,

60. See, e.g., Exec. Order No. 13,563, 76 Fed. Reg. 3,821 (Jan. 21, 2011) (detailing the Executive Order from the Obama Administration); Exec. Order No. 12,866, 58 Fed. Reg. 51,735 (Oct. 4, 1993) (detailing the Executive Order from the Clinton Administration); Exec. Order No. 12,291, 46 Fed. Reg. 13,193 (Feb. 19, 1981) (detailing the Executive Order from the Reagan Administration).

61. See Michael A. Livermore, Cost-Benefit Analysis and Agency Independence, 81 U. CHI. L. REV. 609, 616 (2014) (identifying the goals of centralized review of rulemaking with cost-benefit analysis as reducing information asymmetries and correcting for cognitive biases in agencies to improve the quality of regulation).

62. See id. at 610.

63. OfFice of Mgmt. \& Budget, 2017 Draft Report to Congress ON THE Benefits and Costs of Federal Regulations and Agency Compliance with the UNFUNDED MANDATES REFORM ACT 2 (2017), https://www.whitehouse.gov/wpcontent/uploads/2017/12/draft_2017_cost_benefit_report.pdf

[https://perma.cc/TD9W-RURG].

64. Id. at 10,12 .

65. See generally U.S. Envtl. Prot. Agency, The Benefits and Costs of the Clean Air ACt From 1990 to 2020 (2011) [hereinafter EPA, BENEFITS AND CosTs, 1990 TO 2020], https://www.epa.gov/sites/production/files/2015-07/ 
covering the period from 1990 to 2020 , projected that the statute would produce annual net benefits - benefits minus costs - of $\$ 1.9$ trillion by 2020.66

Two rules, the MATS rule and the CPP, are good examples of the enormous net benefits that can accrue from environmental regulations. The regulatory impact analysis of MATS estimated net benefits of $\$ 27$ to $\$ 80$ billion. ${ }^{67}$ The CPP analysis estimated net benefits of $\$ 26$ to $\$ 45$ billion. ${ }^{68}$ Despite these enormous net benefits, both rules are being reconsidered by the Trump Administration. ${ }^{69}$

These net benefits are so large because the rules save a large number of lives in addition to preventing serious health effects such as heart attacks, strokes, and asthma episodes. The prospective study of the Clean Air Act found that controlling air pollution prevented 160,000 premature deaths in the United States in 2010, rising to 230,000 deaths prevented annually by $2020 .{ }^{70}$ As a result, about two million American lives will be saved in the decade between 2010 and 2020. Just one of these rules, CSAPR, which was upheld by the

documents/fullreport_rev_a.pdf [https://perma.cc/M788-Q4W3]; U.S. ENVTL. PROT. Agency, The Benefits AND Costs of the Clean Air ACt 1990 to 2010 (1999) [hereinafter EPA, BENEFITS AND COSTS, 1990 TO 2010], https://www.epa.gov/ sites/production/files/2015-07/documents/fullrept.pdf [https://perma.cc/PGS6AENN]; U.S. Envtl. Prot. Agency, The Benefits and Costs of the Clean Air Aст 1970 TO 1990 (1997) [hereinafter EPA, BENEFITS AND Costs, 1970 To 1990], https://www.epa.gov/sites/production/files/2015-06/documents/contsetc.pdf [https://perma.cc/TA4Y-N8QU].

66. EPA, BENEFITS AND COSTS, 1990 TO 2020, supra note 65, at 7-9 tbl.7-5.

67. U.S. Envtl. Prot. Agency, Regulatory Impact Analysis for the FinAl Mercury AND Air Toxics StandARDS, at ES-2 tbl.ES-1 (2011), https://www3.epa.gov/ttn/ecas/regdata/RIAs/matsriafinal.pdf [https://perma.cc/RCK8-SKLC].

68. U.S. Envtl. Prot. Agency, Regulatory Impact Analysis for the Clean Power Plan Final Rule, at 8-3 tbl.8-1, 8-4 tbl.8-2 (2015), https://www3.epa.gov/ttnecas $1 /$ docs/ria/utilities_ria_final-clean-power-planexisting-units_2015-08.pdf [https://perma.cc/7R4C-FNG2].

69. See State Guidelines for Greenhouse Gas Emissions from Existing Electric Utility Generating Units, 82 Fed. Reg. 61,507 (proposed Dec. 28, 2017) (to be codified at 40 C.F.R. pt. 60) (giving an advance notice of proposed rulemaking intended to solicit comments for possible replacement for the Clean Power Plan); Respondent EPA's Motion to Continue Oral Argument at 1-4, Murray Energy Corp. v. EPA, No. 16-1127 (D.C. Cir. Apr. 18, 2017) (requesting a continuance for oral argument to allow EPA to review the MATS rule).

70. EPA, BENEFITS AND COSTS, 1990 TO 2020, supra note 65 , at 5-25 tbl.5-6 (including statistics for adults thirty years old and older). 
Supreme Court in a six to two vote,,$^{71}$ is predicted to prevent between 13,000 and 34,000 premature deaths each year. ${ }^{72}$

Systematizing and improving the methodology underlying costbenefit analyses to ensure regulations will actually benefit the American people has been an important push in administrative law in the last few decades, beginning with President Reagan issuing the first Executive Order to require a cost-benefit analysis for major regulations. ${ }^{73}$ In the case of these Clean Air Act regulations, all the available studies forcefully demonstrate that the benefits to the American people substantially outweigh the compliance costs for the affected industries.

\section{SEPARATION OF POWERS CONCERNS}

The fourth claim - that what the agencies have done is an affront to separation of powers - is similarly without merit. To unpack this critique, it is helpful to distinguish two types of arguments that are leveled against the executive branch. The first type of argument criticizes the broad delegation of lawmaking power by Congress to administrative agencies. ${ }^{74}$ The second focuses on the increasing

71. See EPA v. EME Homer City Generation, L.P., 134 S. Ct. 1584, 1593 (2014).

72. U.S. Envtl. Prot. Agency, Regulatory Impact Analysis for the FinAL TRANSPORT RULE 3 (2011), https://www.epa.gov/sites/production/files/201707/documents/epa-hq-oar-2009-0491-4547.pdf [https://perma.cc/W4KE-JM77].

73. See Richard L. Revesz \& Michael A. Livermore, Retaking Rationality: How Cost-Benefit Analysis Can Better Protect the ENVIRONMENT AND OUR HEALTH 24-29, 47-51 (2008).

74. See Christopher C. DeMuth, Can the Administrative State Be Tamed?, 8 J. Legal ANALYSIS 121, 128-33 (2016) (providing historical perspective on the development of the non-delegation doctrine); see also, e.g., Alexander Volokh, Judicial Non-Delegation, the Inherent-Powers Corollary, and Federal Common Law, 66 EMORY L.J. 1391, 1393 (2017) (calling the nondelegation doctrine "notoriously lax" or even "kind of fictitious"); Neomi Rao, Administrative Collusion: How Delegation Diminishes the Collective Congress, 90 N.Y.U. L. REV. 1463, 1484 (2015) (arguing that delegation diminishes Congress as a body by empowering individual legislators to "pursue their personal interests apart from the legislative process"); Gary Lawson, Delegation and Original Meaning, 88 VA. L. Rev. 327, 332 (2002) (claiming that delegation "raises fundamental questions about democracy, accountability, and the enterprise of American governance"). Not all commentators agree that a strong nondelegation doctrine would be desirable or constitutionally justified. See, e.g., Eric A. Posner \& Adrian Vermeule, Interring the Nondelegation Doctrine, 69 U. CHI. L. REV. 1721, 1722 (2002) (arguing that the nondelegation doctrine "lacks any foundation in constitutional text and structure, in standard originalist sources, or in sound economic and political theory"); David B. Spence \& Frank Cross, A Public Choice Case for the Administrative State, 89 GEO. L.J. 97, 133 (2000) (contending that "[d]elegation is efficient in that it offers the opportunity for flexible, adaptive 
importance of the personality of the president to shape and control policymaking, at the expense of Congress. ${ }^{75}$ While the first considers Congress's role in giving up its power to agencies, the second considers the president's role in seizing power through policy setting in or oversight of agencies. ${ }^{76}$

Though recent criticism of the administrative state has become increasingly framed in constitutional terms, ${ }^{77}$ it is still laced with a presumption that there is too much federal regulation - that the federal government is too large and does too much. ${ }^{78}$ However, most

policymaking" and that the nondelegation doctrine "seems to promote form over substance").

75. See, e.g., DeMuth, supra note 74, at 151-52 (describing executive branch decision-making under President Obama, especially with his personal involvement, as "sheer unilateralism"); Daphna Renan, Pooling Powers, 115 Colum. L. Rev. 211, 236 (2015) (describing the ability of the President to pool administrative powers from different agencies as "hold[ing] special promise for the executive in times of polarized and divided government"); Aaron J. Saiger, Obama's "Czars" for Domestic Policy and the Law of the White House Staff, 79 FordHAM L. REv. 2577, 2583 (2011) (claiming that President Obama's "proliferation of high-profile czars is his particular instantiation of a policy, common to all modern Presidents, of seeking to magnify his control over agency action"); Peter L. Strauss, Overseer, or "The Decider"? The President in Administrative Law, 75 GeO. WASH. L. REv. 696, 704-05 (2007) (arguing presidential supervision of agencies is lawful, but exercise of decisional authority is not); see also supra Part II. Again, not all commentators denounce executive unilateralism as undesirable or unlawful. See, e.g., Kirti Datla \& Richard L. Revesz, Deconstructing Independent Agencies (and Executive Agencies), 98 CORNELL L. REV. 769, 774 (2013) (supporting the legal authority of the President to subject all agencies, including independent agencies, to regulatory review); Elena Kagan, Presidential Administration, 114 HARV. L. REV. 2245, 2251 (2001) (defending the use of presidential directives to agencies).

76. See DeMuth, supra note 74, at 128-33, 151-52.

77. See Philip Hamburger, The Administrative Threat 1-4 (2017) (noting that "[o]ver the past century, most complaints about administrative power have come from an economic perspective," before introducing a legal challenge to administrative power); Metzger, supra note 1, at 9 (observing that the "striking feature" of present challenges is that they are "framed in terms of constitutional doctrine").

78. See, e.g., DeMuth, supra note 74, at 173 (claiming that "the removal of limits on Congress's legislative powers and on its ability to delegate those powers... produces too much law"); Cass R. Sunstein \& Adrian Vermeule, Libertarian Administrative Law, 82 U. CHI. L. REV. 393, 402 (2015) (noting that some current critiques of the administrative state espouse a libertarian view that the Constitution should protect property rights and economic rights from governmental intrusion); Christopher W. Schmidt, The Tea Party and the Constitution, 39 Hastings Const. L.Q. 193, 194 (2011) (arguing that two pillars of the Tea Party are that the text of the Constitution contains "the solutions to the problems facing the United States today" and that "the overarching purpose of the Constitution is to ensure that the role of government ... is a limited one"); Spence \& Cross, supra note 74, at 99 (considering seminal early public choice scholarship that implied that, because 
commentators, including many critics, admit that in our modern society some level of congressional delegation and executive branch regulation-including regulation to protect the environment and public health - is desirable and constitutionally permissible. ${ }^{79}$

Though there have been significant nondelegation challenges to the Clean Air Act, the law and the rulemaking framework it establishes for the EPA have been repeatedly upheld by courts. In 1999, the D.C. Circuit considered a direct constitutional challenge to a provision of the Clean Air Act on nondelegation grounds. ${ }^{80}$ Though the D.C. Circuit held that the provision, as interpreted by the EPA, lacked a sufficient "intelligible principle" and was therefore an unconstitutional delegation, ${ }^{81}$ the Supreme Court reversed. ${ }^{82}$ Justice Scalia, writing for a unanimous Court, conceded that a "certain degree of discretion, and thus of lawmaking, inheres in most executive or judicial action," thereby sanctioning the fundamental constitutional framework of legislative delegation to administrative agencies. ${ }^{83}$ Regarding the EPA's first efforts to regulate greenhouse gases, which came before the Supreme Court in Massachusetts v. EPA, opponents argued that the EPA was overstepping its statutory authority because Congress enacted the Clean Air Act of 1970 to address local pollutants and not global pollutants like greenhouse gases. ${ }^{84}$ However, when

interest groups dominated government decision making, "less government might be better government").

79. See Clifford Winston, Government Failure Versus Market FAILURE 42 (2006) (noting that "externalities have caused serious social problems justifying government intervention"); Metzger, supra note 1, at 15 (observing that new efforts to dismantle the administrative state are unlikely to succeed and that "[a]dministrative government's endurance reflects basic political as well as economic, social, and technological realities"); J. Harvie Wilkinson III, Assessing the Administrative State, 32 J.L. \& PoL. 239, 242 (2017) (highlighting that the administrative state "arose out of a deeply felt need to respond to economic crises, intransigent forms of discrimination, and threats to public health and safety - a set of problems that were more complex, more challenging, and more pressing than anything the country had seen before"); Christopher C. DeMuth \& Douglas H. Ginsburg, Rationalism in Regulation, 108 Mich. L. REV. 877, 881 (2010) (reviewing RichARD L. Revesz \& Michael A. Livermore, Retaking Rationality: How Cost-Benefit Analysis Can Better Protect the Environment and Our Health (2008) and observing that "there is little academic disagreement about the need for regulation," including environmental regulation).

80. See Am. Trucking Ass'ns v. EPA, 175 F.3d 1027, 1033-34 (D.C. Cir. 1999), rev'd sub nom. Whitman v. Am. Trucking Ass'ns, 531 U.S. 457 (2001).

81. Am. Trucking Ass'ns, 175 F.3d at 1034.

82. See Whitman, 531 U.S. at 486.

83. Id. at 475. But see id. at 486-87 (Thomas, J., concurring) (suggesting that there are cases where "the significance of the delegated decision is simply too great" for Congress to delegate even with an "intelligible principle").

84. See Massachusetts v. EPA, 549 U.S. 497, 512 (2007). 
Congress passed the law in 1970, it decided not to exhaustively name the particular pollutants that should be regulated, instead delegating to the EPA the determination of what qualified as an "air pollutant" for the purposes of the statute, responding as new scientific evidence emerged. ${ }^{85}$ Applying the statutory definition of "air pollutant" in this case, the Court held that greenhouse gases are air pollutants for the purposes of the Clean Air Act. ${ }^{86}$ Notably, the decision in this case set aside an EPA determination not to regulate greenhouse gases ${ }^{87}$ so the claim of agency overreach in regulating greenhouse gases is particularly puzzling.

EPA regulation of greenhouse gas emissions following Massachusetts v. EPA hardly seems like a poster child for executive branch overreach. The EPA needed to determine whether greenhouse gases, which the Supreme Court had determined to be an air pollutant, posed a danger to public health and welfare. ${ }^{88}$ And, after the endangerment finding, the agency needed to set an appropriate safety standard. ${ }^{89}$ The endangerment finding and rules that set appropriate safety standards are technical, fact-intensive determinations that fall comfortably within the expertise of the EPA. Whether the limit for an

85. See John C. Dernbach, The Unfocused Regulation of Toxic and Hazardous Pollutants, 21 HARV. ENVTL. L. ReV. 1, 42 (1997) (describing how "[t]he Clean Air Act authorizes EPA to add or remove pollutants on its own or in response to a petition from any person"). The specific statutory authority at issue in this case reads:

The Administrator shall by regulation prescribe (and from time to time revise) in accordance with the provisions of this section, standards applicable to the emission of any air pollutant from any class or classes of new motor vehicles or new motor vehicle engines, which in his judgment cause, or contribute to, air pollution which may reasonably be anticipated to endanger public health or welfare.

42 U.S.C. $\S 7521(\mathrm{a})(1)$ (2012). The Clean Air Act defines the term "air pollutant" broadly: "The term 'air pollutant' means any air pollution agent or combination of such agents, including any physical, chemical, biological, radioactive (including source material, special nuclear material, and byproduct material) substance or matter which is emitted into or otherwise enters the ambient air." 42 U.S.C. § 7602(g) (2012). In the opinion, the Court argues that while the drafting Congress "might not have appreciated the possibility that burning fossil fuels could lead to global warming, they did understand that without regulatory flexibility, changing circumstances and scientific developments would soon render the Clean Air Act obsolete." Massachusetts v. EPA, 549 U.S. at 532.

86. See id. at 528-29 ("On its face, the definition embraces all airborne compounds of whatever stripe .... The statute is unambiguous.").

87. See id. at 534-35 (finding that the "EPA has offered no reasoned explanation for its refusal to decide whether greenhouse gases cause or contribute to climate change").

88. See $§ 7521(\mathrm{a})(1)$.

89. See id. 
air pollutant should be eight parts per million or ten parts per million, for example, is not the kind of decision Congress is well-suited to make. Not only would the substance of regulation likely suffer, but forcing Congress to make technical decisions like this would significantly add to its workload, distracting from other legislation Congress might focus on instead. Again, if we accept the proposition that some congressional delegation of rulemaking authority is desirable and constitutionally permissible, delegating to the EPA the authority to set standards to control air pollutants under the Clean Air Act is an eminently reasonable and uncontroversial delegation.

Turning then to the second critique - that the power of the president has eclipsed that of Congress, resulting in strong, unilateral agenda-setting by the president, including through policy setting at administrative agencies - there seems to be fairly broad consensus on the general diagnosis of the current power dynamic between Congress and the president. ${ }^{90}$ However, just because the president's individual significance has grown in the government does not mean that the exercise of executive power or that agency decision-making are legally unaccountable. Though President Obama urged his EPA to initiate new regulations to protect the environment, the EPA had to act within its statutory authority and follow the notice-and-comment rulemaking procedures laid out in the Administrative Procedure Act (APA). ${ }^{91}$ On the other side of the ideological spectrum, deregulatory actions taken by President Trump's EPA are being scrutinized in the courts for their conformity with statutory mandates and APA procedures as well. ${ }^{22}$ In both the Obama and Trump Administrations, the requirement for reasoned decision-making under the APA has provided a legitimate check on untethered presidential policy-making

90. Compare DeMuth, supra note 74 , at 173 (describing the "current freewheeling unilateralism" of executive government in America, in the context of a critique of expansive executive branch power), with ERIC A. POSNER \& ADRIAN Vermeule, The Executive Unbound: After the Madisonian Republic 32-33 (2010) (agreeing that the executive is largely unconstrained by Congress but arguing that our government is better off as a result).

91. See, e.g., Util. Air Regulatory Grp. v. EPA, 134 S. Ct. 2427, 2449 (2014) (holding that the "EPA exceeded its statutory authority when it interpreted the Clean Air Act to require . . . permitting for stationary sources based on their greenhouse-gas emissions"); EPA v. EME Homer City Generation, L.P., 134 S. Ct. 1584, 1600 (2014) (holding, for the CSAPR, that the EPA adhered to statutorily mandated deadlines under the Clear Air Act and that a failure to promulgate a rule by the deadline would have violated the statute).

92. See Coral Davenport \& Lisa Friedman, In His Haste to Roll Back Rules, Scott Pruitt, EPA Chief, Risks His Agenda, N.Y. Times (Apr. 7, 2018), https://www.nytimes.com/2018/04/07/climate/scott-pruitt-epa-rollbacks.html [https://perma.cc/DDS4-TUBB]. 
and has promoted respect for congressional will and the text of the Clean Air Act. ${ }^{93}$

\section{A MORE RoBUSt CONGRESSIONAL ROLE?}

Fifth, the current calls for congressional action are not efforts to improve regulatory policy or, for that matter, to deal with any separation of powers problems. Instead, they are part of a concerted campaign, motivated by a myopic focus on reducing compliance costs, to put an end to the protections that save so many lives and produce such large net benefits. This strategy is clear from the bills that have been introduced in the recent Congresses.

The proposed Regulatory Accountability Act (RAA) (the most recent version of which passed in the House in 2017 but not the Senate) would increase the procedural formality required for rulemaking. ${ }^{4}$ The RAA would make it easy for the regulated community to obtain a trial-like hearing for significant rules and essentially turn notice-and-comment rulemaking, which is currently used to promulgate virtually all significant regulations, ${ }^{95}$ into formal rulemaking. ${ }^{96}$ This is not a recipe to improve the quality of agency

93. See Util. Air Regulatory Grp., 134 S. Ct. at 2449 (holding that Obama's EPA exceeded its statutory authority); Clean Air Council v. Pruitt, 862 F.3d 1, 10 (D.C. Cir. 2017) (holding that Trump's EPA, in reconsidering a rule, acted in an "arbitrary and capricious" way in violation of the APA).

94. See Regulatory Accountability Act of 2017, H.R. 5, 115th Cong. (2017).

95. See Anne Joseph O'Connell, Political Cycles of Rulemaking: An Empirical Portrait of the Modern Administrative State, 94 VA. L. REV. 889, 936 (2008) (presenting empirical data that shows notice-and-comment rulemaking is the predominant mechanism of rulemaking for many agencies). A few agencies rely less heavily on notice-and-comment rulemaking, such as the Department of Defense and the State Department, which are largely exempted from the APA's notice-andcomment requirements, and the Department of Homeland Security and the Federal Emergency Management Agency, which rely on emergency rationales for interim rulemaking, which are similarly exempt from notice-and-comment requirements. See $i d$. at 935 . The EPA, by contrast, relies almost exclusively on notice-and-comment rulemaking. See id.

96. See John Conyers, Jr. et al., The Dangers of Legislating Based on Mythology: The Serious Risks Presented by the Anti-Regulatory Agenda of the 115th Congress and the Trump Administration, 54 HARV. J. ON LEGIS. 365, 383-84 (2017) (criticizing the proposal as an attempt to revive "formal rulemaking"); Richard J. Pierce, Jr., A Good Effort, with One Glaring Flaw, REg. REv. (May 8, 2017), https://www.theregreview.org/2017/05/08/pierce-good-effort-glaringflaw/ [https://perma.cc/V6L5-Y4U7] (criticizing the public hearing provision of the RAA, which could be triggered in more than 100 agency rulemakings a year, as "a variant of 'formal rulemaking"'); James Goodwin, Anything but Moderate: The Senate Regulatory Accountability Act of 2017, CPRBLOG (May 2, 2017), http://www.progressivereform.org/CPRBlog.cfm?idBlog=B6B0B417-E50E-5626- 
decision-making. It is, instead, a recipe to significantly delay and perhaps defeat action of any kind. ${ }^{97}$ Formal rulemaking has few defenders in the legal academy, ${ }^{98}$ as it was widely held to be unworkable by the time it was effectively interred in the 1973 Supreme Court case, United States v. Florida East Coast Railway Company. ${ }^{99}$ The roadblock imposed by formal rulemaking was encapsulated in the infamous "peanut butter rule," in which it took over ten years to determine whether peanut butter should consist of $87 \%$ or $90 \%$ peanuts. ${ }^{100}$

Another proposed bill, the Regulations from the Executive in Need of Scrutiny (REINS) Act of 2017, ${ }^{101}$ would be similarly cumbersome and would similarly stand in the way of the promulgation of socially beneficial regulations. ${ }^{102}$ The REINS Act would require all

FCB79F4E27E24532 [https://perma.cc/ZEJ9-6JGY] (criticizing the requirement for formal, trial-like procedures in the RAA as exclusionary to the public due to requirements for legal counsel).

97. See Letter from Forty-Two Admin. Law Professors, to Lamar Smith, Chairman, Comm. on the Judiciary, and John Conyers, Jr., Ranking Member, Comm. on the Judiciary (Oct. 24, 2011), http://democrats.judiciary.house.gov/sites/

democrats.judiciary.house.gov/files/LawReg111024.pdf [https://perma.cc/CZ38$5 \mathrm{AQB}]$ (describing a "consensus of the administrative law community that the APA formal rulemaking procedure is unworkable and obsolete"); Am. Bar Ass'n Section of Administrative Law \& Regulatory Practice, Comments on H.R. 3010, The Regulatory Accountability Act of 2011, 64 ADMIN. L. REV. 619, 626 (2012) (noting that formal rulemaking has been "long-discredited" and that trial-like procedures are ill-suited for legislative decision-making); William Funk, Requiring Formal Rulemaking Is a Thinly Veiled Attempt to Halt Regulation, REG. Rev. (May 18, 2017), https://www.theregreview.org/2017/05/18/funk-formal-rulemaking-halt-regulation/ [https://perma.cc/CH3K-Y7ZP] (highlighting that "the U.S. Supreme Court, scholars, policy makers, and other interested parties all have condemned formal rulemaking").

98. See generally Aaron L. Nielson, In Defense of Formal Rulemaking, 75 OHIO ST. L.J. 237 (2014) (describing the general academic consensus that formal rulemaking is obsolete, while arguing for limited adoption of more formal procedures in narrow circumstances).

99. See United States v. Fla. E. Coast Ry. Co., 410 U.S. 224, 234-35 (1973) (holding that the statutory language in the case was insufficient to trigger formal rulemaking under the APA). This holding made it easy for agencies to avoid formal rulemaking in the context of statutes that were not exactly tailored to the language of the APA. Congress also demurred from insisting on formal rulemaking in subsequent legislation.

100. See Peanut Butter, Definition and Standard of Identity; Findings of Fact, Conclusions, and Final Order, 33 Fed. Reg. 10,506 (July 24, 1968). The rule was upheld by the Third Circuit two years later, bringing the total time from initial proposal to the court decision to over ten years. See generally Corn Prods. Co. v. FDA, 427 F.2d 511 (1970).

101. See Regulations from the Executive in Need of Scrutiny Act of 2017, H.R. 26, 115th Cong. (2017).

102. See Inst. for Policy Integrity, The REINS Act Is Burdensome, IRRATIONAL, AND LEGALLY QUESTIONABLE 2 (2017), http://policyintegrity.org/ 
major regulations to be approved by both houses of Congress and signed by the president before going into effect. ${ }^{103}$ If Congress failed to act, the agency would be barred from promulgating a related rule for the duration of that session. ${ }^{104}$ Congress would effectively have the power to veto regulation through inaction.

Congress has neither the time nor relevant expertise to effectively review complicated regulations - the safety standard of an air pollutant requisite to protect human health, for example-which can take years to formulate through the notice-and-comment process. The REINS Act would not only greatly hamper the ability of agencies to promulgate rules, it would also incentivize gridlock in Congress for any member promoting an anti-regulatory agenda: If merely delaying a congressional vote on a regulation would be enough to kill that and any similar regulation, obstruction becomes as powerful as, and significantly easier than, passing a law limiting agency authority.

Additionally, even if Congress does vote to authorize the rule, the REINS Act would not prevent subsequent legal challenges on administrative law grounds. ${ }^{105}$ The Act specifically provides that congressional authorization of a rule would not affect the substantive standard of review by the courts. ${ }^{106}$ In effect, the procedure of congressional approval in the REINS Act would not even confer the benefit of finality that congressional action normally would.

There is no doubt that some forms of congressional action could be desirable. For example, while the EPA has the authority to regulate greenhouse gases under the Clean Air Act, as the Supreme Court

files/publications/Senate_REINS.pdf [https://perma.cc/9HDM-J9RN] (noting not only the burden the REINS Act would place on Congress, but also that it would empower special interests to block regulation); Ronald M. Levin, The REINS Act: Unbridled Impediment to Regulation, 83 GEO. WASH. L. REV. 1446, 1455 (2015) (noting that in 2010 the House had only 116 legislative days while the REINS Act then being considered would have required more than 100 regulations to be reviewed); Metzger, supra note 1, at 12-13 (arguing that the difficulty Congress has had in passing legislation in recent years would mean the REINS Act would effectively block major regulation).

103. See H.R. $26 \S \S 801,802$.

104. See id. $\S 801(\mathrm{a})(5)$.

105. See id. $\S 805(\mathrm{c})$.

106. See id. § 805(c). Section 805(c) reads:

The enactment of a joint resolution of approval under section 802 shall not be interpreted to serve as a grant or modification of statutory authority by Congress for the promulgation of a rule, shall not extinguish or affect any claim, whether substantive or procedural, against any alleged defect in a rule, and shall not form part of the record before the court in any judicial proceeding concerning a rule except for purposes of determining whether or not the rule is in effect.

Id.; see also Levin, supra note 102, at 1462. 
recognized in Massachusetts v. EPA, ${ }^{107}$ doing so through regulation is cumbersome and suboptimal. For example, $\S 111(\mathrm{~d})$ of the Clean Air Act, under which the EPA promulgated the Clean Power Plan, probably requires the EPA to proceed sector by sector, with one regulation for power plants, another one for oil and gas installations, yet another one for refineries, and so on. ${ }^{108}$ And each state must draw up plans to show how the requirements of each rule would be met in that state. ${ }^{109}$ As a result, it is difficult to benefit from inter-sector and inter-state trading options, which could significantly reduce the costs of greenhouse gas reductions. Legislation, in contrast, could be designed to achieve this objective. And the regulatory process is cumbersome and open to protracted judicial challenges, which legislation would avoid. But constructive congressional action of this sort seems unlikely in the current political climate.

\section{THE CURRENT ADMINISTRATION'S DISREGARD FOR COST- BENEFIT ANALYSIS}

This brings me to my final, deep concern. Since 1981, administrations of both parties have determined that regulations should be justified by reference to cost-benefit analysis. ${ }^{110}$ This requirement has served us well until recently. As discussed with the example of the enormous net-benefits of the Clean Air Act, the proof is in the pudding. ${ }^{111}$

But now, the Trump Administration has mounted an attack on cost-benefit analysis across a number of different regulatory areas. First, President Trump's Executive Order 13,771 requires a cap on costs, suggesting that the goal is to minimize overall regulatory costs, not to maximize the net benefits of regulation. ${ }^{12}$ Any respected economist would cringe at this one-sidedness. ${ }^{113}$ It would be absurd

107. See Massachusetts v. EPA, 549 U.S. 497, 532 (2007); see also supra text accompanying notes 84-89.

108. See 42 U.S.C. § 7411(b)(1)(A), (d)(1) (2012); Linda Tsang, Cong. Research Serv., R44615, EPA's Methane Regulations: Legal Overview 2-3 (2018), https://fas.org/sgp/crs/misc/R44615.pdf [https://perma.cc/QBQ5-37BW].

109. See 40 C.F.R. § 60.24(c) (2018); JAYNI Foley HEIN, CAPTURING VAluE: Science and Strategies to Curb Methane Emissions From the OIL and NATURAL GAS SECTOR 11 (2014), http://policyintegrity.org/files/publications/

Capturing_Value_-_Methane_Policy_Brief.pdf [https://perma.cc/C7E3-B2NF].

110. See supra notes $\overline{60}-61$ and accompanying text.

111. See supra Part III.

112. See Exec. Order No. 13,771, 82 Fed. Reg. 9,339 (Feb. 3, 2017).

113. See Karl S. Coplan, The Missing Element of Environmental Cost-Benefit Analysis: Compensation for the Loss of Regulatory Benefits, 30 GEO. ENVTL. L. REV. 
for the economic analysis of policy to ignore the deaths averted, the reduced number of hospitalizations, the morbidity reductions, and other significant decreases in the well-being of Americans.

Second, the Trump Administration has justified a number of its efforts to delay, stay, or suspend Obama Administration regulations by reference only to the cost savings to regulated industries, without looking at the forgone benefits to the regulatory beneficiaries. ${ }^{114} \mathrm{On}$ this front, the Trump Administration has already suffered significant losses in the courts, ${ }^{115}$ but these actions, even if ultimately unsuccessful, are revealing of the Administration's mind-set.

Third, the proposed repeals of Obama Administration regulations do violence to cost-benefit analysis. For example, in the proposed repeal to the Clean Power Plan, the EPA analyzes a scenario under which the co-benefits (or indirect benefits) of the regulation are not taken into account, even though the agency urges more extensive consideration of the indirect costs of regulation. ${ }^{116}$ To take into account the indirect negative consequences of regulation but ignore the positive ones is the very embodiment of "arbitrary and capricious" conduct.

The era in which congressional gridlock was counteracted by agencies acting under authority delegated to them by existing statutes and generally guided by cost-benefit analysis brought Americans enormous net benefits, greatly enhancing our well-being. ${ }^{117}$ We have much cleaner air and water and much safer workplaces and consumer products. ${ }^{118}$ And the American economy has grown significantly in the period when all this happened. Unfortunately, we now appear to be entering a time when this desirable state of affairs is at risk. But the courts have the tools they need to ensure that agencies, in their zeal to

281, 284-91 (2018) (summarizing the traditional economic rationale for cost-benefit analysis).

114. See Lydia DePillis, The Real Story of Trump's Crusade to Cut Government Red Tape, CNN BusinEss (June 5, 2018, 7:41 AM), https://money. cnn.com/2018/06/05/news/economy/trump-executive-order-red-tape/index.html [https://perma.cc/L5JB-3U23].

115. See generally Clean Air Council v. Pruitt, 862 F.3d 1 (D.C. Cir. 2017).

116. See Kimberly M. Castle \& Richard L. Revesz, Environmental Standards, Thresholds, and the Next Battleground of Climate Change Regulations, 103 MinN. L. REV. (forthcoming 2019) (manuscript at 2-3) (on file with author); Richard L. Revesz, Pruitt Would Like Us to Ignore the Indirect Benefits of Environmental Regulations, SLATE (June 13, 2018, 12:38 PM), https://slate.com/ technology/2018/06/scott-pruitt-is-trying-to-undermine-environmental-regulationin-a-creative-way.html [https://perma.cc/MB3J-M64E].

117. See supra Part I (explaining the era of successful congressional gridlock).

118. See supra Part III (discussing the studies that show the benefits of clear air regulations). 
deregulate, do not violate the rationality requirements embodied in the APA and well-established doctrines of administrative law. 